Магомедова А.Г. Приостановление работы как правомерный способ получения невыплаченной заработной платы

УДК 347

DOI: 10.21779/2500-1930-2019-34-4-139-147

\title{
А.Г. Магомедова
}

\section{Приостановление работы как правомерный способ получения невыплаченной заработной платы}

Дагестанский государственный университет, Россия, 367000, г. Махачкала, ул. М. Гаджиева 43a, amina2170@yandex.ru

В статье исследуются вопросы, связанные с особенностями реализации положений трудового законодательства, устанавливающего гарантии работнику в случае задержки или невыплаты в полном объеме заработной платы. Особое внимание уделено рассмотрению такого способа восстановления нарушенного права работника, как самозащита, которая выражается в приостановлении работы по причине невыплаты заработной платы работодателем, а также условиям ее правомерности. Проанализирована судебная практика по трудовым спорам, возникшим в результате приостановления работы в связи с задержкой заработной платы. На основании исследования трудового законодательства и судебной практики сделан вывод о необходимости совершенствования трудового законодательства в целях устранения правовых пробелов, касающихся вопросов приостановления исполнения работником трудовых обязанностей вследствие невыплаты работодателем заработной платы.

Ключевые слова: трудовое законодательство, работник, самозащита, приостановление работы, заработная плата, работодатель, ответственность.

Составной частью в структуре доходов работника является заработная плата вознаграждение за труд (ст. 37 Конституции РФ). Оплата труда определяет уровень и качество жизни населения, размер будущей пенсии, возможности образования, культурного развития. Кроме того, заработная плата является главным источником «инвестиций для компенсации износа средств производства и его модернизации» [1, с. 17]. В свою очередь, несвоевременная выплата заработной платы приводит к снижению результативности труда, потере интереса у работника к выполнению трудовых обязанностей, неудовлетворительной трудовой дисциплине и другим негативным последствиям, что отрицательно сказывается на эффективности экономики в целом. Несмотря на принимаемые меры по обеспечению конституционных гарантий по оплате труда, в России все еще существуют задолженности по выплате заработной платы ${ }^{10}$. В связи с этим проблемы правового регулирования в сфере защиты права работника на получение своевременной и в полном объеме выплаты заработной платы все чаще становятся предметом исследования правоведов [2, с. 103; 3, с. 215; 4, с. 40; 5, с. 112].

\footnotetext{
${ }^{10}$ По данным Росстата, задолженность по заработной плате на 1 сентября 2019 г. имелась перед 40,0 тыс. человек (менее $1 \%$ работников по обследуемым видам экономической деятельности), из них $48 \%$ - работники обрабатывающих производств; $16 \%$ - строительства; $12 \%$ - сельского хозяйства, охоты и предоставления услуг в этих областях, лесозаготовок; 7 \% - транспорта; $6 \%$ - добычи полезных ископаемых. (О просроченной задолженности по заработной плате на 1 сентября 2019 года. - Режим доступа: https://nangs.org/analytics/rosstat-o-prosrochennojzadolzhennosti-po-zarabotnoj-plate (дата обращения: 01.11.2019)).
} 
Магомедова А.Г. Приостановление работы как правомерный способ получения невыплаченной заработной платы

Российское трудовое законодательство, восприняв положения международных правовых актов в сфере труда ${ }^{11}$, а также нормы Конституции РФ, закрепляет гарантии права работника на своевременную и в полном объеме выплату заработной платы. Сроки получения работником заработной платы устанавливаются также коллективным договором, правилами внутреннего трудового распорядка, трудовыми договорами, заключаемыми между работодателем и работником (ст. 136 ТК РФ).

Для защиты нарушенного права большое значение имеет фундаментальное положение Конституции, предусматривающее возможность человека самостоятельно защищать свои права всеми законными способами (ч. 2 ст. 45), конкретизированное в трудовом законодательстве. Так, согласно ч. 1 ст. 352 Трудового кодекса каждый работник вправе использовать все возможные способы защиты своих трудовых прав, не запрещенные законом. А в соответствии с ч. 2 ст. 352 в числе основных способов защиты трудовых прав работников обозначена самозащита, под которой понимается возможность субъекта права защищать себя собственными действиями. Одним из способов самозащиты, который может использовать работник, является приостановка работы. Трудовой кодекс приводит исчерпывающий перечень случаев, когда приостановка работником работы будет правомерной и не повлечет применение мер дисциплинарной ответственности (ст. 142 ТК РФ). Трудовое законодательство устанавливает определенные правовые требования к действиям работника, который собирается прибегнуть к самозащите нарушенного права на оплату труда: он обязан письменно известить работодателя о приостановлении работы на весь период при задержке заработной платы на срок свыше пятнадцати дней [6, с. 78]. Отказ работника от выполнения работы как форма самозащиты трудовых прав (ст. 379 ТК РФ) «является мерой вынужденного характера, предусмотренной законом для стимулирования работодателя к обеспечению выплаты работникам определённой трудовым договором заработной платы в установленные сроки» [7, с. 28].

В пункте 57 Постановления пленума Верховного Суда РФ указано, что «приостановить работу работник может независимо от наличия вины работодателя в невыплате заработной платы. В период приостановления работы работник вправе отсутствовать на рабочем месте» [8].

Законодателем закреплен четкий перечень случаев, когда приостановление работы работником не допускается:

- в периоды введения военного и чрезвычайного положения;

- в военных органах и организациях, ведающих вопросами обеспечения обороны страны и безопасности государства, аварийно-спасательных, поисково-спасательных, противопожарных работ, работ по предупреждению или ликвидации стихийных бедствий и чрезвычайных ситуаций, в правоохранительных органах;

- на государственной службе;

- в организациях, непосредственно обслуживающих особо опасные виды производств, оборудования;

- на производстве, связанном с обеспечением жизнедеятельности населения (энергообеспечение, отопление и тепло-, водо- и газоснабжение, связь); на станции скорой и неотложной медицинской помощи.

Перечисленные исключения не противоречат конституционным положениям о самозащите, поскольку установлены федеральным законодательством и правоприменительной практикой Конституционного Суда РФ [9]. При этом работники таких органи-

${ }^{11}$ Конвенция МОТ № 95 «Относительно защиты заработной платы» (1949 г.). - Доступ из справ.-правовой системы «КонсультантПлюс». 
Магомедова А.Г. Приостановление работы как правомерный способ получения невыплаченной заработной платы

заций, не наделенные правомочием реализовать самозащиту нарушенных прав путем приостановления трудовых обязанностей вследствие задержки или неполной выплаты работодателем заработной платы, вправе обратиться в комиссию по трудовым спорам, в суд либо в органы государственного надзора и контроля за соблюдением трудового законодательства. Иначе к работнику, чья работа связана с опасным производством или обеспечением жизнедеятельности населения, в случае прекращения им работы из-за задержки заработной платы применяются меры ответственности.

Приведем пример из судебной практики. В.В. Смолин, являясь машинистомкочегаром котельной отделения ООО «Тепло-Водо-Ресурс», самовольно прекратил работу в период отопительного сезона, рассматривая это как единственное средство разрешения коллективного или индивидуального трудового спора. ООО «Тепло-ВодоРесурс» обеспечивает тепло- и водоснабжение жилых домов и социальных объектов, в связи с чем проведение забастовок и приостановление деятельности котельных в целях урегулирования трудовых споров запрещено. В нарушение действующего законодательства в помещении котельной состоялась забастовка работников в связи с невыплатой заработной платы за февраль-март 2016 г., результаты которой с требованиями о погашении задолженности по заработной плате были зафиксированы протоколом. Директор ООО «Тепло-Водо-Ресурс» сообщил о том, что работники самовольно, без предварительного уведомления приостановили работу котельных, чем создали угрозу возникновения чрезвычайной ситуации. Согласно объяснениям В.В. Смолина в конце марта в центральной котельной состоялось общее собрание работников, на котором в присутствии директора ООО «Тепло-Водо-Ресурс» было принято решение о приостановлении работы котельной, если до конца марта работникам не будет выплачена заработная плата. Поскольку денежные средства не поступили, В.В. Смолин решил приостановить работу. Суд, учитывая положения ст. 143 ТК РФ, предусматривающей в соответствии со ст. 55 Конституции РФ случаи и основания признания забастовок незаконными и не допускающимися в организациях, непосредственно связанных с обеспечением жизнедеятельности населения, в отношении В.В. Смолина возбудил дело об административном правонарушении, предусмотренном ч. 1 ст. 20.26 КоАП РФ [10].

В таких случаях на работников будет наложено дисциплинарное взыскание за нарушение трудовой дисциплины, а представительный орган работников, осуществляющий незаконную деятельность, обязан возместить убытки, причиненные работодателю, за счет своих средств, определенных судом.

Следует отметить, что в юридической литературе разделялись мнения относительно размера выплаты работнику заработной платы за период приостановления работы. Так, до принятия Федерального закона [11] ч. 4 ст. 142 ТК РФ одни специалисты утверждали, что выплата должна осуществляться в соответствии с положениями ст. 157 ТК, регулирующими правила оплаты времени простоя. Другие, напротив, руководствуясь ст. 142 и 236 ТК РФ, считали необходимым обязать работодателя «начислять заработную плату за весь период приостановки работы в полном объеме» [12, c. 19]. Введение в ст. 142 ТК РФ конкретизирующей нормы, регулирующей оплату времени приостановления работником трудовых обязанностей вследствие невыплаты заработной платы, направлено на устранение существующих законодательных пробелов и расхождений в судебной практике, поскольку судами выносились решения «то в пользу работника, то в пользу работодателя» [13, с. 406].

В настоящий момент установлено, что время приостановки работы должно быть оплачено исходя из среднего заработка. Рассмотрим пример. Пастух И.В. обратилась в суд с иском к ООО «КамгэсЗЯБ» о взыскании среднего заработка за период приостановления работы. В обоснование иска истец в заявлении указал, что с 16 сентября 
Магомедова А.Г. Приостановление работы как правомерный способ получения невыплаченной заработной платы

2014 года он состоял в трудовых отношениях с ООО «КамгэсЗяб» на основании трудового договора. Работодатель регулярно задерживал выплату заработной платы, в связи с чем истец в письменном виде заявил работодателю о приостановлении работы в соответствии со ст. 142 ТК РФ. С 23 ноября до 11 декабря 2015 года включительно истец не работал (6 дней в ноябре 2015 года и 9 дней в декабре 2015 года). 14 декабря 2015 года он вышел на работу, так как часть заработной платы была выплачена. 15 декабря 2015 года он вновь подал работодателю заявление о приостановлении работы по ст. 142 ТК РФ в связи с задержкой выплаты заработной платы за октябрь 2015 года, подлежащей выплате до 30 декабря 2015 года, на основании которого он приостановил работу с 21 по 28. декабря 2015 года на весь период до выплаты задержанной суммы заработной платы и не работал в декабре 2015 года 7 дней. Ответчик иск не признал, указав, что ч. 4 ст. 142 Трудового кодекса РФ о сохранении за работником среднего заработка на период приостановления работы, введенная Федеральным законом от 30.12.2015 г. № 434-Ф3, вступила в силу с 10.01.2016 года, а потому к заявленным истцом требованиям не применяется. Ответчиком не была произведена оплата периода приостановки работы из расчета среднего заработка, что нарушило права истца.

Суд удовлетворил данный иск, признав приостановление работы истцом правомерным исходя из п. 57 Постановления Пленума Верховного Суда РФ от 17.03.2004 г. № 2, и вынес решение о взыскании среднего заработка в пользу истца, поскольку Трудовым кодексом РФ в спорный период специально не было предусмотрено иное, работник имеет право на сохранение среднего заработка за все время задержки выплаты заработной платы, включая период приостановления работы [14].

Законодателем также регламентирован порядок выхода на работу работника, отсутствовавшего на рабочем месте во время приостановления трудовых обязанностей: он должен приступить к работе не позднее следующего рабочего дня после получения письменного уведомления от работодателя о готовности произвести выплату задержанной заработной платы в день выхода работника. В случае нарушения работодателем установленного срока выплаты заработной платы, оплаты отпуска, выплат при увольнении и (или) других выплат, причитающихся работнику, он обязан выплатить их с уплатой процентов (денежной компенсации) согласно ст. 236 ТК РФ.

По мнению некоторых авторов, установленный в ст. 236 ТК РФ порядок выплаты дополнительной компенсации за дни задержки оплаты труда не в полной мере восполняет материальные потери работника. Поэтому в научной литературе предлагается воспринять опыт зарубежных стран и законодательно закрепить положение о том, что «при задержке выплаты заработной платы работодатель выплачивает работнику 5-8 \% от суммы образовавшейся задолженности за первую неделю и 10 \% за каждую последующую неделю» [15, с. 42].

Следует особо подчеркнуть, что исходя из ст. 236 ТК обязанность по выплате денежной компенсации возникает у работодателя с первого дня задержки причитающихся работнику выплат и не зависит от наличия его вины. Даже в случаях невыплаты заработной платы ввиду отсутствия в организации денежных средств либо в случае банкротства, либо в связи с непоступлением денежных средств из бюджета, работники все равно будут иметь право на денежную компенсацию в связи с задержкой заработной платы.

В качестве примера из судебной практики можно привести решение Ленинградского районного суда г. Калининграда по делу № 2-1963/2019 в котором суд удовлетворил исковые требования И.Г. Андреева к ООО «Реставрационный Проект» о взыскании задолженности по заработной плате в пользу истца. Судом было установлено, что 16 октября 2017 года Арбитражный Суд г. Москвы вынес решение, в соответствии 
Магомедова А.Г. Приостановление работы как правомерный способ получения невыплаченной заработной платы

с которым ООО «Реставрационный проект» признано несостоятельным (банкротом), в отношении ответчика открыто конкурсное производство сроком на 6 месяцев и утвержден конкурсный управляющий. 20 октября 2017 года между конкурсным управляющим и И.Г. Андреевым был заключен срочный трудовой договор, в соответствии с которым И.Г. Андреев был принят на работу в ООО «Реставрационный проект» на должность начальника юридического отдела с установленной заработной платой в размере 100000 рублей. С марта 2018 г. истцу не выплачивалась заработная плата, в связи с чем с 4 июня 2018 г. он приостановил трудовую деятельность до полной выплаты заработной платы с соответствующим уведомлением конкурсного управляющего. Решением Ленинградского районного суда г. Калининграда от 15 ноября 2018 года в пользу истца с ответчика была взыскана задолженность по заработной плате в размере 310 018,54 руб. за период с 1 марта 2018 г. по 3 июня 2018 г. и средний заработок за время приостановления трудовой деятельности за период с 4 июня 2018 г. по 31 октября 2018 г. в размере 535991,89 руб. Вместе с тем решение суда не было исполнено. Задолженность по заработной плате с 1 ноября 2018 г. по 31 марта 2019 г. составила 500000 руб., которую и просил взыскать с ООО «Реставрационный проект» в свою пользу И.Г. Андреев [16].

Сравнительно новой формой восстановления прав граждан, осуществляющих трудовую деятельность, является компенсация морального вреда $[17$, с. 130], которая назначается судом и в случаях правомерного приостановления трудовых обязанностей работником из-за задержки заработной платы по требованию истца. Так, например, paботнице был выплачен средний заработок и компенсирован моральный вред за время приостановки трудовых обязанностей в связи с задержкой выплаты заработной платы, несмотря на то, что она на момент обращения в суд находилась в отпуске по уходу за ребенком до достижения им возраста полутора лет. В обоснование заявленных требований она указала на то, что работала инженером I категории группы создания баз данных отдела Цифровой картографии и геоинформационных систем Производственного управления в ОАО «Госземкадастрсъемка»- ВИСХАГИ. С февраля 2014 г. ответчик не выплачивал заработную плату, поэтому с 25.08.2014 по 12.07.2015 г. истцом в установленном законом порядке была приостановлена работа в связи с невыплатой заработной платы. Суд рассмотрел все обстоятельства дела и пришел к выводу о правомерности требований истца [18].

В некоторых случаях работодатели увольняют работников за период приостановления работы за невыплату заработной платы, квалифицируя такое отсутствие на работе, как прогул, что приводит к возникновению судебных споров.

Например, Д.И. Евсеев обратился в суд с иском к ООО «СЕРВИС-АВТО» о взыскании задолженности по заработной плате, компенсации за несвоевременную выплату заработной платы, компенсации морального вреда. Исковые требования мотивированы тем, что Д.И. Евсеев с 01.04.2018 г. был принят на работу в ООО «СЕРВИС-АВТО» на должность водителя автобуса с установленным ежемесячным должностным окладом. В нарушение действующего законодательства выплата заработной платы Д.И. Евсееву за период его трудовой деятельности в ООО «СЕРВИС-АВТО» осуществлялась не в полном объеме: с апреля 2018 г. по ноябрь 2018 г. у ответчика перед истцом образовалась задолженность по заработной плате. Истец неоднократно обращался к ответчику с требованием о выплате задолженности по заработной плате, но 01.12.2019 курьерской службой истцу была доставлена его трудовая книжка с вкладышем, направленная ответчиком по адресу регистрации истца, в которую ответчик внес запись (приказ № 17 от 30.11.2018) об увольнении истца по основанию, предусмотренному подпунктом «а» п. 6 ч. 1 ст. 81 ТК РФ (прогул). Истец не согласился с таким основанием увольнения и 
Магомедова А.Г. Приостановление работы как правомерный способ получения невыплаченной заработной платы

считал само увольнение незаконным, так как 30.11.2018 г., руководствуясь положениями ст. 142 ТК РФ, известил работодателя и приостановил трудовую деятельность с 01.12.2018 г.

В суде истец утверждал, что предупредил работодателя о приостановке работы, отправив соответствующее уведомление по юридическому адресу ответчика, и в качестве доказательства предоставил почтовую квитанцию. В ходе судебного разбирательства ответчиком был представлен отзыв, согласно которому истец был уволен по собственному желанию на основании личного заявления, что не соответствовало действительности, поскольку данное заявление истец не писал, с приказом об увольнении ознакомлен не был, письменного объяснения о причинах отсутствия на работе работодатель от него не затребовал. В результате суд признал увольнение незаконным и восстановил истца на работе, а также взыскал с ответчика заработную плату за время вынужденного прогула, задолженность по заработной плате за апрель 2018 г., компенсацию за задержку выплаты заработной платы за период с 15.05.2018 по 29.05.2019 гг., а также компенсацию морального вреда [19].

Анализ трудового законодательства и судебной практики позволил сделать вывод, что в целом закон предусматривает систему гарантий, позволяющих реализовывать право работника на своевременную и в полном объеме выплату заработной платы.

Приведенные выше примеры свидетельствуют о том, что применение такого способа защиты трудовых прав, как самозащита, не всегда бывает достаточно эффективным, и работникам часто приходится восстанавливать свои нарушенные права традиционными методами, обращаясь в уполномоченные государственные органы и в суды.

При этом приостановление работы, которая представляет собой временный отказ от выполнения трудовых обязанностей, может применяться как средство самозащиты только при наличии достаточных правовых оснований, закрепленных в законодательстве.

Представляется, что «характер принятых изменений в действующее законодательство указывает на общую тенденцию к усилению ответственности работодателей за невыплату или неполную выплату заработной платы и иных выплат, причитающихся работникам» [20, с. 31]. Однако все еще существуют пробелы в правовом регулировании данной сферы, требующие устранения, поскольку единственным средством самозащиты работника, согласно трудовому законодательству, является приостановление работы.

\section{Литература}

1. Абузярова Н.A. Конституционные основы заработной платы и социального страхования в России // Журнал Российского права. - 2016. - № 7. - С. 17.

2. Григорьева А.Г., Леус М.В. Вопросы правового регулирования задержки выплаты заработной платы // Гуманитарные, социально-экономические и общественные науки. - 2017. - № 10. - С. 103-105.

3. Багмет А.М., Богуславский А.М. Проблемы законодательства и правоприменения в вопросах невыплаты заработной платы // Вестник Южно-Уральского государственного университета. Сер.: Право. - 2006. - № 5 (60). - С. 215-218.

4. Костян И.А. К вопросу о защите трудовых прав работников // Трудовое право в России и за рубежом. - 2016. - № 4. - С. 40.

5. Князева Н.A. Защита прав работников на своевременную и в полном объеме выплату заработной платы // Актуальные проблемы российского права. - 2019. - № 1 (98). - C. 112. 
Магомедова А.Г. Приостановление работы как правомерный способ получения невыплаченной заработной платы

6. Бубнова M. Как уведомить работодателя о приостановке работы из-за невыплаты зарплаты // Трудовое право. - 2019. - № 8. - С. 78.

7. Байдина $O$. Приостановление работы как гарантия получения заработной платы: как это работает // Трудовое право. - 2017. - № 9. - С. 28.

8. О применении судами Российской Федерации Трудового кодекса Российской Федерации: Постановление Пленума Верховного Суда Рос. Федерации от 17 марта 2004 г. № 2: в ред. от 24 ноября 2015 г. // Доступ из справ.-правовой системы «КонсультантПлюс».

9. Об отказе в принятии к рассмотрению жалобы гражданина Сазонова Владимира Григорьевича на нарушение его конституционных прав положениями статей 124, 142 и 234 Трудового кодекса Российской Федерации: Определение Конституционного Суда РФ от 02.03.2006 г. № 60-О // Доступ из справ.-правовой системы «КонсультантПлюс».

10. Постановление по делу об административном правонарушении от 11 мая 2016 года Мирового Суда судебного участка № 2 Ширинского района Республики Хакасия. - Режим доступа: https://rospravosudie.com/court-sudebnyj-uchastok-mirovogosudi-2-shirinskogo-rajona-s/act-229286305/ (дата обращения: 04.11.2019).

11. О внесении изменений в статью 142 Трудового кодекса Российской Федерации: Федеральный закон Рос. Федерации от 30 дек. 2015 г. № 434-Ф3 // Доступ из справ.-правовой системы «КонсультантПлюс».

12. Карпушкин A.B. Конституционно-правовые гарантии защиты прав работников при задержке выплаты заработной платы // Известия высших учебных заведений. Поволжский регион. - 2011. - № 1 (17). - С. 19.

13. Коваленко Е.А., Мекленбуриев А.М. Правоприменительная практика по спорам о заработной плате // Традиции и инновации в современной науке: XVI Межд. научнопрактическая конференция. [Электронный ресурс]. - М.: Олимп, 2016. - С. 406-407.

14. Решение Набережночелнинского городского суда (Республика Татарстан) № 2-2845/2016 2-2845/2016 M-234/2016 М-234/2016 от 16 марта 2016 г. по делу № 2-2845/2016. - Режим доступа: https://sudact.ru/regular/doc/8G2rxNyymCUR / (дата обращения: 10.11.2019).

15. Аббасова E.B. О дополнительных мерах по обеспечению своевременной выплаты заработной платы // Вестник Южно-Уральского государственного университета. Сер.: Право. - 2017. - Т. 17, № 4. - С. 41-44.

16. Решение Ленинградского районного суда г. Калининграда (Калининградская область) № 2-1963/2019 2-1963/2019 М-843/2019 М-843/2019 от 28 мая 2019 г. по делу № 2-1963/2019. - Режим доступа: https://sudact.ru/regular/doc/FqLGRSkQvVl/ (дата обращения: 10.11.2019).

17. Сакаева К.У. Некоторые вопросы компенсации морального вреда в трудовом праве России // Вестник СевКавГТИ. - 2015. - Вып. 4 (23). - С. 130.

18. Решение суда о взыскании среднего заработка за период приостановления работы в связи с задержкой выплаты заработной платы и компенсации морального вреда № 02-5228/2016. - Режим доступа: http://sud-praktika.ru/precedent/171880.html (дата обращения: 10.11.2019).

19. Решение Электростальского городского суда (Московская область) № 2-484/2019 2-484/2019 М-7/2019 М-7/2019 от 29 мая 2019 г. по делу № 2-484/2019. Режим доступа: https://sudact.ru/regular/doc/D9kRb6tHo2NE/ (дата обращения: 11.11.2019).

20. Мацкевич O.B. Модернизация системы гарантий своевременной выплаты заработной платы // Юридическое образование и наука. - 2017. - № 5. - С. 31-35. 
Магомедова А.Г. Приостановление работы как правомерный способ получения невыплаченной заработной платы

\section{References}

1. Abuzyarova N.A. Konstitutsionnye osnovy zarabotnoi platy i sotsial'nogo strakhovaniya v Rossii // Zhurnal Rossiiskogo prava. - 2016. - № 7. - S. 17.

2. Grigor'eva A.G., Leus M.V. Voprosy pravovogo regulirovaniya zaderzhki vyplaty zarabotnoi platy // Gumanitarnye, sotsial'no-ekonomicheskie i obshchestvennye nauki. 2017. - № 10. - S. 103-105.

3. Bagmet A.M., Boguslavskii A.M. Problemy zakonodatel'stva i pravoprimeneniya v voprosakh nevyplaty zarabotnoi platy // Vestnik Yuzhno-Ural'skogo gosudarstvennogo universiteta. Ser.: Pravo. - 2006. - № 5 (60). - S. 215-218.

4. Kostyan I.A. K voprosu o zashchite trudovykh prav rabotnikov // Trudovoe pravo v Rossii i za rubezhom. - 2016. - № 4. - S. 40.

5. Knyazeva N.A. Zashchita prav rabotnikov na svoevremennuyu i v polnom ob»eme vyplatu zarabotnoi platy // Aktual'nye problemy rossiiskogo prava. - 2019. - № 1 (98). Yanvar'. - S. 112.

6. Bubnova $M$. Kak uvedomit' rabotodatelya o priostanovke raboty iz-za nevyplaty zarplaty// Trudovoe pravo. - 2019. - № 8. - S. 78.

7. Baidina $O$. Priostanovlenie raboty kak garantiya polucheniya zarabotnoi platy: kak eto rabotaet // Trudovoe pravo. - 2017. - № 9. - S. 28.

8. O primenenii sudami Rossiiskoi Federatsii Trudovogo kodeksa Rossiiskoi Federatsii: postanovlenie Plenuma Verkhovnogo Suda Ros. Federatsii ot 17 marta 2004 g. № 2: v red. ot 24 noyab. 2015 g. Dostup iz sprav.-pravovoi sistemy «Konsul'tantPlyus».

9. Ob otkaze v prinyatii k rassmotreniyu zhaloby grazhdanina Sazonova Vladimira Grigor'evicha na narushenie ego konstitutsionnykh prav polozheniyami statei 124, 142 i 234 Trudovogo kodeksa Rossiiskoi Federatsii: Opredelenie Konstitutsionnogo Suda RF ot 02.03.2006 g. № 60-O. Dostup iz sprav.-pravovoi sistemy «Konsul'tantPlyus».

10. Postanovlenie po delu ob administrativnom pravonarushenii ot 11 maya 2016 goda Mirovogo suda sudebnogo uchastka № 2 Shirinskogo raiona Respubliki Khakasiya. URL: https://rospravosudie.com/court-sudebnyj-uchastok-mirovogo-sudi-2-shirinskogo-rajonas/act-229286305/ (data obrashcheniya: 04.11.2019).

11. O vnesenii izmenenii v stat'yu 142 Trudovogo kodeksa Rossiiskoi Federatsii: feder. zakon Ros. Federatsii ot 30 dek. 2015 g. № 434-FZ. Dostup iz sprav.-pravovoi sistemy «Konsul'tantPlyus»».

12. Karpushkin A.V. Konstitutsionno-pravovye garantii zashchity prav rabotnikov pri zaderzhke vyplaty zarabotnoi platy // Izvestiya vysshikh uchebnykh zavedenii. Povolzhskii region. - 2011. - № 1 (17). - S. 19.

13. Kovalenko E.A., Meklenburtsev A.M. Pravoprimenitel'naya praktika po sporam o zarabotnoi plate // Traditsii i innovatsii v sovremennoi nauke: XVI Mezhdunarodnaya nauchno-prakticheskaya konferentsiya [Elektronnyi resurs]. M.: Olimp, 2016. - S. 406-407.

14. Reshenie Naberezhnochelninskogo gorodskogo suda (Respublika Tatarstan) № 2-2845/2016 2-2845/2016 M-234/2016 M-234/2016 ot 16 marta 2016 g. po delu № 2-2845/2016. URL: https://sudact.ru/regular/doc/8G2rxNyymCUR/ (data obrashcheniya: 10.11.2019).

15. Abbasova E.V. O dopolnitel'nykh merakh po obespecheniyu svoevremennoi vyplaty zarabotnoi platy // Vestnik Yuzhno-Ural'skogo gosudarstvennogo universiteta. Ser. Pravo. 2017. - T. 17, № 4. - S. 41-44.

16. Reshenie Leningradskogo raionnogo suda g. Kaliningrada (Kaliningradskaya oblast') № 2-1963/2019 2-1963/2019 M-843/2019 M-843/2019 ot 28 maya 2019 g. po delu № 2-1963/2019. URL: https://sudact.ru/regular/doc/FqLGRSkQvVl/ (data obrashcheniya: 10.11.2019). 
Магомедова А.Г. Приостановление работы как правомерный способ получения невыплаченной заработной платы

17. Sakaeva K.U. Nekotorye voprosy kompensatsii moral'nogo vreda v trudovom prave Rossii // Vestnik SevKavGTI. - 2015. - Vyp. 4 (23). - S. 130.

18. Reshenie suda o vzyskanii srednego zarabotka za period priostanovleniya raboty $\mathrm{v}$ svyazi s zaderzhkoi vyplaty zarabotnoi platy i kompensatsii moral'nogo vreda № 02-5228/2016. URL: http://sud-praktika.ru/precedent/171880.html (data obrashcheniya: 10.11.2019).

19. Reshenie Elektrostal'skogo gorodskogo suda (Moskovskaya oblast') № 2-484/2019 2-484/2019 M-7/2019 M-7/2019 ot 29 maya 2019 g. po delu № 2-484/2019. URL: https://sudact.ru/regular/doc/D9kRb6tHo2NE/ (data obrashcheniya: 11.11.2019).

20. Matskevich O.V. Modernizatsiya sistemy garantii svoevremennoi vyplaty zarabotnoi platy // Yuridicheskoe obrazovanie i nauka. - 2017. - № 5. - S. 31-35.

Поступила в редакиию 17 ноября 2019 г.

УДК 347

DOI: $10.21779 / 2500-1930-2019-34-4-139-147$

\section{Work suspension as a legitimate way to receive unpaid wages}

\section{A.G. Magomedova}

Dagestan State University; Russia, 367000, Makhachkala, M. Gadzhiev st., 43a; amina2170@yandex.ru

The article is devoted to the study of issues related to the peculiarities of the implementation of the provisions of labor legislation establishing guarantees to the employee in case of delay or nonpayment of wages in full. Special attention is paid to the consideration of such a method of restoring the violated right of an employee as self-defense, which is expressed in the suspension of work due to non-payment of wages by the employer, as well as the conditions of its legality. Judicial practice on labor disputes arising as a result of suspension of work in connection with the delay of wages is analyzed. Based on the study of labor legislation and judicial practice, conclusions are drawn about the need to improve labor legislation in order to eliminate legal gaps relating to the suspension of performance of labor duties by an employee due to non-payment of wages by the employer.

Keywords: labor legislation, employee, self-defense, suspension of work, wages, employer, responsibility.

Received 17 November, 2019 